\title{
Distribution, Ecological Risk Assessment, and Bioavailability of Cadmium in Soil from Nansha, Pearl River Delta, China
}

\author{
Fangting Wang ${ }^{1}$, Changsheng Huang ${ }^{2, *}$, Zhihua Chen ${ }^{1}$ and Ke Bao ${ }^{3}$ \\ 1 School of Environmental Studies, China University of Geosciences, Wuhan 430074, China; \\ ftwang1991@cug.edu.cn (F.W.); zhchen@cug.edu.cn (Z.C.) \\ 2 Wuhan Geological Survey Center, China Geological Survey, Wuhan 430205, China \\ 3 Changjiang Water Resources Commission of the Ministry of Water Resources, Wuhan 430010, China; \\ kebao@cug.edu.cn \\ * Correspondence: cshuang@cug.edu.cn
}

Received: 16 August 2019; Accepted: 25 September 2019; Published: 27 September 2019

\begin{abstract}
Background: Cadmium (Cd) pollution poses a threat to human health. Examination of the spatial distribution of $\mathrm{Cd}$ in soils can be used to assess the risks posed to humans and the environment. Objective: This study determined the enrichment rules and factors influencing $\mathrm{Cd}$ pollution in Nansha, and evaluated the pollution characteristics and bioavailability of $\mathrm{Cd}$ in quaternary sediments through 7 deep soil profiles $(0-200 \mathrm{~cm}), 4$ boreholes, and 348 topsoil $(0-20 \mathrm{~cm})$ samples. Methods: The geo-accumulation index (Igeo) and the potential ecological risk index (Er) were used to assess ecological risk, and bioavailability was determined using multivariate, spatial distribution, and correlation matrix analyses. Results: From the Er, 52\% of Nansha was classed as being at very high risk of $\mathrm{Cd}$ pollution; a further $36 \%$ was classed as dangerous. Cadmium was more abundant in clay soils than in sandy soils. Bioavailable Cd in quaternary sediments was significantly affected by the total $\mathrm{Cd}$, and labile $\mathrm{Cd}$ accounted for more than half of the total $\mathrm{Cd}$. Changes in $\mathrm{pH}$ mainly affected bioavailable $\mathrm{Cd}$ rather than total $\mathrm{Cd}$, affecting the overall bioavailability of $\mathrm{Cd}$. Conclusions: Nansha soils are commonly and seriously contaminated with $\mathrm{Cd}$. An appropriate remediation treatment approach should be used to reduce Cd bioavailability. Furthermore, planting structures in farmland should be adjusted to avoid the impact of heavy metals on human health.
\end{abstract}

Keywords: heavy metal; spatial distribution; ecological risk assessment; cadmium bioavailability

\section{Introduction}

Rapid urbanization is a worldwide phenomenon accompanied by intensive industrial and economic activities and environmental problems, especially in developing countries [1]. Industrialization/urbanization (e.g., industry, agriculture, and transportation) and natural geological processes can lead to the heavy metal pollution of some farmland soils [2,3]. Heavy metals in soils pose a threat to human health through the food chain $[4,5]$, and cadmium (Cd) is an important pollutant among various heavy metal elements, due to its high migration rate from soil to plants and strong biological toxicity [6]. There is increasing evidence that environmental exposure to $\mathrm{Cd}$ is associated with increased cancer incidence [7]. The excessive input of heavy metals into soils has attracted extensive worldwide attention due to their toxicity, durability, and biological enrichment [8], and heavy metal pollution in soil has become a globally recognized environmental problem [9]. The soil pollution situation is a particular problem in China. The development of industry and agriculture has meant that $\mathrm{Cd}$ in soil has significantly increased due to the extensive application of fertilizers and pesticides, the agricultural utilization of industrial wastewater and sludge, and the increasing 
atmospheric deposition of heavy metals. Cadmium pollutants were found to exceed the standard at $7.0 \%$ of the survey points within 6.3 million square kilometers, according to the National Soil Pollution Condition Investigation Gazette (2014). The area of Cd-contaminated farmland is $2800 \mathrm{~km}^{2}$, and some sewage-irrigated areas are used to produce "Cd rice" [10], which generally refers to rice of which the cadmium content exceeds the standard. The safety standard for cadmium in rice in China is $0.2 \mathrm{mg} / \mathrm{kg}$, The annual output of Cd-contaminated agricultural products exceeds 1.5 million tons [11].

In recent years, researchers have paid more attention to the spatial distribution of heavy metals in soils in order to assess the potential risks to humans and the environment [6,12-14]. The spatial distribution of pollutants has been used to quantify the level of pollution in an area, and the identification of influencing factors can be used to measure the effectiveness of pollution abatement measures [15]. Previous studies have investigated the effect of soil parent material [16,17], soil type and physicochemical properties [18-21], the water environment [22], atmospheric deposition [23,24], and human activities (traffic emissions, industrial emissions, etc.) $[25,26]$ on soil Cd pollution. However, the impact of these different factors is often regional. Therefore, it is necessary to conduct a more in-depth analysis of the degree and scope of the influence of these factors on soil $\mathrm{Cd}$ pollution. Although the total heavy metal levels in a soil can reflect the degree of enrichment by heavy metals in soils, the bioaccessibility and biotoxicity of heavy metals are more dependent on their fractionation bioavailability [27], which has gradually become an important basis for soil pollution assessment and risk prediction [17].

This study took the Nansha District of the Pearl River Delta, China, as the research area. Field sampling and laboratory sample analyses were undertaken, with the objectives of (1) quantifying and determining the spatial distribution patterns of soil Cd in the Nansha district; (2) assessing Cd pollution levels and potential ecological risks; and (3) quantifying the bioavailability of $\mathrm{Cd}$ and identifying the factors affecting $\mathrm{Cd}$ bioavailability in the soil. The data obtained in this study will provide a basis for the prevention, treatment, and remediation of soil Cd pollution in farmland around cities.

\section{Materials and Methods}

\subsection{Study Area}

Nansha District is a municipal district of Guangzhou, Guangdong Province, which became the sixth new national area in October, 2012. It is located at the southernmost end of Guangzhou city on the west bank of the Humen waterway, which is part of the Pearl River. It is where the Xijiang River, Beijiang River, and Dongiiang River converge, and is in the geometric center of the Pearl River Delta, which is the channel from the Pearl River basin to the ocean. The landforms in Nansha are hilly, marine-terrigenous plains, and tidal flats. The low hills are mainly distributed around Huangshanlu Mountain and the highest point in the region is $295.3 \mathrm{~m}$ above sea level. The marine-terrigenous plains are distributed in Huangge and Hengli; the upper part is silt or silty soil (sand) and the lower part is river-deposited sand. The tidal flats are mainly distributed in the southeastern area of Wanqingsha, Longxue Island, and the Xinken coast. The terrain is zonal, parallel to the coast, broad, and gentle. In March, 2017, the development plan for the Guangdong-Hong Kong-Macao greater bay area was proposed. Nansha, as the geometric center of the greater bay area, is also the pivot for Guangzhou's development of the "One Belt One Road" initiative, and the maritime Silk Road forms the Guangdong-Hong Kong-Macao international strategic platform for the greater bay area.

\subsection{Sampling}

The topsoil $(0-20 \mathrm{~cm})$ sampling points were based on the 1:50,000 standard map, and the density was generally four samples per $\mathrm{km}^{2}$. A total of 348 samples were collected, based on geological background, land use, and the topographical and geomorphic characteristics of the sampling cells (Figure 1). During sampling, wooden sampling tools were used to collect 0-20 cm depth cubic soil columns, and the weeds, grass roots, gravel, fertilizer clumps, and other sundries in the samples were 
removed. One sample was taken as a fixed point and combined with 3-5 sub-samples collected within a radius of $50 \mathrm{~m}$ to increase the representativeness of the soil samples. The samples were placed in new, sealed bags.



Figure 1. Topsoil sampling sites in Nansha District (Guangzhou, Guangdong Province, China).

Seven deep soil $(0-200 \mathrm{~cm})$ profiles were arranged according to the soil genetic type, including that of residual sediments and alluvium. A hand drill was used to collect $0-2 \mathrm{~m}$ sections, and the soil in contact with the sampling tool was removed. Each section was divided into five samples $(0-20 \mathrm{~cm}$, 20-50 cm, 50-100 cm, 100-150 cm, and 150-200 cm), which were placed into new, sealed bags.

Four boreholes from the land to the sea, which exposed the quaternary sediments, were selected as sampling points, numbered NSGC27, NSGC05, NSGC11, and NSGC39. The sampling depth of the boreholes was $48.3 \mathrm{~m}, 32.5 \mathrm{~m}, 43.7 \mathrm{~m}$, and $37.8 \mathrm{~m}$, respectively, until fully weathered bedrock was reached. Stratified sampling was adopted to stratify the section according to the sedimentary material or lithology, and equally spaced samples were taken according to the thickness of each layer.

\subsection{Laboratory Analysis}

The samples were analyzed in the laboratory for soil acidity, cation exchange capacity (CEC), soil organic matter $(\mathrm{SOM})$, potassium $(\mathrm{K})$, calcium $(\mathrm{Ca})$, sodium $(\mathrm{Na})$, magnesium $(\mathrm{Mg})$, aluminum $(\mathrm{Al})$, copper $(\mathrm{Cu})$, arsenic $(\mathrm{As})$, mercury $(\mathrm{Hg})$, zinc $(\mathrm{Zn})$, iron $(\mathrm{Fe})$, manganese $(\mathrm{Mn})$, titanium $(\mathrm{Ti})$, lead $(\mathrm{Pb})$, cadmium $(\mathrm{Cd})$, silicon dioxide $\left(\mathrm{SiO}_{2}\right)$, boron $(\mathrm{B})$, barium $(\mathrm{Ba})$, strontium $(\mathrm{Sr})$, and the contents of the seven morphological forms of $\mathrm{Cd}$.

In accordance with Determination of $\mathrm{pH}$ Value in Forest Soil (LY/t1239-1999), soil acidity was determined using the ion-selective electrode method/pH meter, $\mathrm{CEC}$ was determined by the ammonium acetate exchange method, and SOM was determined by the potassium dichromate volume method. Potassium, calcium, sodium, magnesium, aluminum, copper, zinc, iron, and manganese were determined by inductively coupled plasma emission spectrometry/thermoelectric ICAP6300 in accordance with Analysis Methods for Regional (DZ/t0279.2-2016); arsenic and mercury were determined by atomic fluorescence spectrometry in accordance with Soil Testing (NY/t1121.10-2006); lead and $\mathrm{Cd}$ were determined by inductively coupled plasma mass spectrometry/thermoelectric 
X2 according to Analysis Methods for Regional (DZ/t0279.3-2016); titanium, lead, silicon dioxide, barium, and strontium were determined by powder compaction-X-ray fluorescence spectrometry in the Netherlands in accordance with Analysis Methods for Regional (DZ/t0279.1-2016); and boron was determined by AC arc emission spectrometry in accordance with Analysis Methods for Regional (DZ/t0279.1-2016). The seven-step sequential extraction method recommended by the Technical Requirements for Analysis of Ecological Geochemical Evaluation Samples (DD2005-03) was used to analyze the seven forms of $\mathrm{Cd}$, namely water-soluble, exchangeable, carbonate-bound, humic-acid-bound, Fe-Mn-oxide-bound, refractory-organic-matter-bound, and residual fractions. The details of each step of the protocol are given in Table 1.

Table 1. Sequential extraction methods for $\mathrm{Cd}$ in different depth soils from the study area.

\begin{tabular}{|c|c|c|c|c|}
\hline Step & Fractions & Extract Composition & $\mathrm{pH}$ & Notes \\
\hline F1 & Water soluble & $25 \mathrm{~mL}$ ultrapure water & $\mathrm{pH}=8.0 \pm 0.2$ & $\begin{array}{c}30 \mathrm{~min} \text { ultrasound }(40 \mathrm{KHz} \\
\left.25 \pm 5^{\circ} \mathrm{C}\right) \text {, rinse with ultrapure } \mathrm{H}_{2} \mathrm{O} \text {. }\end{array}$ \\
\hline F2 & Exchangeable & $25 \mathrm{~mL} 1.0 \mathrm{~mol} / \mathrm{L} \mathrm{MgCl} 2 \cdot 6 \mathrm{H}_{2} \mathrm{O}$ & $\mathrm{pH}=7.0 \pm 0.2$ & $\begin{array}{c}30 \mathrm{~min} \text { ultrasound }(40 \mathrm{KHz} \\
\left.25 \pm 5^{\circ} \mathrm{C}\right) \text {, rinse with ultrapure } \mathrm{H}_{2} \mathrm{O} \text {. }\end{array}$ \\
\hline F3 & Carbonate-bound & $\begin{array}{c}25 \mathrm{~mL} 1.0 \mathrm{~mol} / \mathrm{L} \\
\mathrm{CH}_{3} \mathrm{COONa} \cdot 3 \mathrm{H}_{2} \mathrm{O}\end{array}$ & $\mathrm{pH}=5.0 \pm 0.2$ & $\begin{array}{c}60 \mathrm{~min} \text { ultrasound }(40 \mathrm{KHz} \\
\left.25 \pm 5^{\circ} \mathrm{C}\right) \text {, rinse with ultrapure } \mathrm{H}_{2} \mathrm{O}\end{array}$ \\
\hline F4 & Humic-acid-bound & $50 \mathrm{~mL} 0.1 \mathrm{~mol} / \mathrm{L} \mathrm{Na}_{4} \mathrm{PO}_{7} \cdot 10 \mathrm{H}_{2} \mathrm{O}$ & $\mathrm{pH}=10.0 \pm 0.2$ & $\begin{array}{c}40 \mathrm{~min} \text { ultrasound }(40 \mathrm{KHz}, \\
\left.25 \pm 5^{\circ} \mathrm{C}\right) \text {, rinse with ultrapure } \mathrm{H}_{2} \mathrm{O} \text {. }\end{array}$ \\
\hline F5 & Fe-Mn-oxide-bound & $\begin{array}{c}50 \mathrm{~mL} 0.25 \mathrm{~mol} / \mathrm{L} \\
\mathrm{HONH}_{3} \mathrm{Cl}-\mathrm{HCl}\end{array}$ & & $\begin{array}{l}1 \mathrm{~h} \text { ultrasound }\left(40 \mathrm{KHz}, 25 \pm 5^{\circ} \mathrm{C}\right) \\
\text { rinse with ultrapure } \mathrm{H}_{2} \mathrm{O} \text {. }\end{array}$ \\
\hline F6 & Refractory-organic-matter-bound & $3 \mathrm{~mL} \mathrm{HNO}_{3}+5 \mathrm{~mL} 30 \% \mathrm{H}_{2} \mathrm{O}_{2}$ & $\mathrm{pH}=2.0 \pm 0.2$ & $\begin{array}{l}1.5 \mathrm{~h} \text { bath }\left(83^{\circ} \mathrm{C} \text {, stirred every } 10\right. \\
\text { min), another } 1.0 \mathrm{~h} \text { bath with } 3 \mathrm{~mL} \\
30 \% \mathrm{H}_{2} \mathrm{O}_{2}\left(83^{\circ} \mathrm{C} \text {, stirred every } 10\right. \\
\text { min), rinse with ultrapure } \mathrm{H}_{2} \mathrm{O} \text {. }\end{array}$ \\
\hline F7 & Residual & $\begin{array}{c}5 \mathrm{~mL} \text { mixture of } 37 \% \mathrm{HCl}, 70 \% \\
\mathrm{HClO}_{4} \text {, and } 70 \% \mathrm{HNO}(1: 1: 1) / 5 \\
\mathrm{~mL} 40 \% \mathrm{HF}\end{array}$ & & Digested at $105^{\circ} \mathrm{C}$ for $3 \mathrm{~h}$. \\
\hline
\end{tabular}

\subsection{Soil Pollution Evaluation}

\subsubsection{Geo-Accumulation Index}

The geo-accumulation index (Igeo) was originally proposed by Muller (1969) [28] to evaluate the degree of metal pollution in sediments. It is widely used to study the degree of metal enrichment in soil, sediments, and dust. It is defined by the following equation:

$$
\mathrm{I}_{g e o}=\log _{2} \frac{C_{n}}{k B_{n}}
$$

where $C_{n}$ represents the measured concentration of metal $n$ in the soils and $B_{n}$ represents the geochemical background concentration of metal $\mathrm{n}$ in the soils. The constant $\mathrm{k}(\mathrm{k}=1.5)$ is a correction coefficient that helps to account for natural fluctuations and anthropogenic influences. The Igeo values are classified as follows: uncontaminated (Igeo $\leq 0)$, uncontaminated to moderately contaminated $(0<$ Igeo $\leq 1)$, moderately contaminated $(1<$ Igeo $\leq 2)$, moderately to heavily contaminated $(2 \leq$ Igeo $<3)$, heavily contaminated $(3 \leq$ Igeo $<4)$, heavily to extremely contaminated $(4 \leq$ Igeo $<5)$, and extremely contaminated (Igeo $\geq 5$ ).

\subsubsection{Potential Ecological Risk Index (Er)}

The potential ecological risk index (Er) was originally proposed by Hakanson (1980) [29] and is based on sedimentological theory. It not only considers the enrichment level of each element, but also their unique toxicities and comprehensive ecological risk [30]. The Er is calculated as follows [31]:

$$
E_{r}=\frac{C_{i}}{B_{i}} T_{0}
$$

where $\mathrm{T}_{0}$ is the heavy metal toxic response factor. This value is set at 30 for Cd (unitless) [32]. Ci and Bi $(\mathrm{mg} / \mathrm{kg})$ represent the $\mathrm{Cd}$ concentration in the soil samples and the soil $\mathrm{Cd}$ background concentration, 
respectively. The Er is divided into five classifications: low risk $(\mathrm{Er}<40)$; moderate risk $(40 \leq \mathrm{Er}<80)$; considerable risk $(80 \leq \mathrm{Er}<160)$; very high risk $(160 \leq \mathrm{Er}<320)$; and dangerous $(\mathrm{Er} \geq 320)$.

\subsection{Multivariate Statistics and Spatial Analysis Methods}

Descriptive statistics were produced and a correlation analysis was conducted using Microsoft Office documents Excel 2010 (Redmond, WA, USA). The coefficient of variation (CV) is the ratio of standard deviation (SD) to the mean, which reflects the average variation degree of a certain attribute at each sampling point. It is generally considered that the total sample has low spatial variability if $\mathrm{CV}$ $\leq 10 \%$, that the spatial variability is moderate if $10 \%<\mathrm{CV}<100 \%$, and that the spatial variability is strong if $\mathrm{CV} \geq 100 \%$ [33]. A Pearson's correlation matrix (PCM) [34] was prepared, and a hierarchical cluster analysis (HCA) [35] and a principal component analysis (PCA) [36] were performed using IBM SPSS statistics for Windows, version 20.0 (Chicago, Ill, USA) to quantify the correlations between each element. MAPGIS 6.7 software (Wuhan, China) was used to establish the Geosoft binary grid (GRD) mathematical model using the Kring pan-kriging method to construct the discrete data grid, and high level smooth contour line processing was adopted to draw the contour map so that the spatial distribution pattern of the studied metals could be displayed.

\section{Results and Discussion}

\subsection{Spatial Distribution of $C d$ in Soil}

\subsubsection{Vertical Distribution of Cd}

Vertical Distribution of Cd in Deep Soil (0-200 cm)

The $\mathrm{Cd}, \mathrm{pH}, \mathrm{CEC}$, and SOM contents in the residual slope sediments were 0.06 to $0.17 \mathrm{mg} / \mathrm{kg}, 4.95$ to $5.21,3.49$ to $5.64 \mathrm{cmol} / \mathrm{kg}$, and 0.11 to $0.98 \%$, respectively, which meant that they were far lower than in the alluvium. The alluvium analysis results are shown for comparison (Figure 2). The overall trend for $\mathrm{Cd}$ was as follows: the deeper the soil, the lower the $\mathrm{Cd}$ concentration, which was consistent with the gradual decrease in CEC and SOM, but was the reverse of the trend for $\mathrm{pH}$. Due to the large rainfall and the effects of human engineering activity, the $\mathrm{CV}$ for $\mathrm{Cd}$ in the topsoil was greater than in the deep soil, and the $\mathrm{Cd}$ levels in the different profiles at the same burial depth tended to be consistent, especially at $20-50 \mathrm{~cm}$ and $150-200 \mathrm{~cm}$, which was consistent with the change trends for $\mathrm{pH}$ and SOM. NS113PM was the profile in which the Cd content decreased most significantly as soil depth increased. The lowest $\mathrm{Cd}$ contents were found at $150-200 \mathrm{~cm}$ deep for all soil profiles, which corresponded to the generally low CEC, low SOM, and generally high $\mathrm{pH}$ values.



Figure 2. Comparisons between $\mathrm{Cd}, \mathrm{pH}$, cation exchange capacity (CEC), and soil organic matter (SOM) for the different depths and soil profiles. 
Vertical Distribution of Cd in Quaternary Sediments

The Cd concentration in NSGC27 ranged from 55 to $388 \mu \mathrm{g} / \mathrm{kg}$, NSGC05 ranged from 28 to 560 $\mu \mathrm{g} / \mathrm{kg}$, NSGC11 ranged from 54 to $664 \mu \mathrm{g} / \mathrm{kg}$, and NSGC39 ranged from 29 to $573 \mu \mathrm{g} / \mathrm{kg}$ (Table 2). The $\mathrm{Cd}$ was more significantly enriched than the crustal abundance. The total $\mathrm{Cd}$ in the soils of the four drilling profiles was mostly higher than the background concentration for Guangdong Province soil of $56 \mu \mathrm{g} / \mathrm{kg}$. The mean and median concentrations for each drilling were significantly higher than the background concentrations for Chinese soils, continental crust abundance, and the Pearl River sediment of 97,80 , and $90 \mu \mathrm{g} / \mathrm{kg}$ respectively. In general, the Cd concentration tended to decrease as the depth increased (Figure 3). The $\mathrm{Cd}$ in the soils from cores with a depth of $0-10 \mathrm{~m}$ was generally higher than $300 \mu \mathrm{g} / \mathrm{kg}$, and the highest content reached $664 \mu \mathrm{g} / \mathrm{kg}$. In addition, the Cd concentration was low in coarse sediment dominated by sandy soil, whereas it was high in fine sediment dominated by cohesive soil.

Table 2. Cadmium contents in the different cores.

\begin{tabular}{|c|c|c|c|c|c|c|c|}
\hline \multirow{2}{*}{$\begin{array}{l}\text { Boring } \\
\text { Number }\end{array}$} & \multirow{2}{*}{$\begin{array}{c}\text { Number of } \\
\text { Samples }\end{array}$} & MIN $^{1}$ & MAX $^{2}$ & $\mathrm{AVG}^{3}$ & MID $^{4}$ & \multirow{2}{*}{$\mathrm{SD}^{5}$} & \multirow{2}{*}{$\mathrm{CV}^{6}$} \\
\hline & & \multicolumn{4}{|c|}{ Unit: $\mu \mathrm{g} / \mathrm{Kg}$} & & \\
\hline NSGC27 & 24 & 55 & 388 & 209 & 160 & 126 & 0.601 \\
\hline NSGC05 & 7 & 28 & 560 & 273 & 305 & 170 & 0.624 \\
\hline NSGC11 & 23 & 54 & 664 & 299 & 286 & 167 & 0.577 \\
\hline NSGC39 & 21 & 29 & 573 & 238 & 165 & 148 & 0.625 \\
\hline
\end{tabular}

${ }^{1}$ Minimum value, ${ }^{2}$ Maximum value, ${ }^{3}$ Average value, ${ }^{4}$ Mid-value, ${ }^{5}$ Standard deviation, ${ }^{6}$ Coefficient of variation.


Figure 3. $\mathrm{Cd}$, cation exchange capacity (CEC), and soil organic matter (SOM) distribution in the cores.

\subsubsection{The Plane Distribution Pattern for Cd in Topsoil ( $0-20 \mathrm{~cm}$ deep)}

The $\mathrm{pH}$ in the topsoil from Nansha was 4.05 to 8.43 . It was generally neutral to acidic, but in some local areas it was weakly alkaline. The $\mathrm{pH}$ was higher on both sides of the Jiaomen River and near the Pearl River estuary, and lower in Hengli, Wanqingsha, and Nansha (Figure 4). The pH of the red soil area was generally lower than that of other soil types due to the overlying slope deposit of fully weathered granite. The lowest $\mathrm{pH}$ for the red soil was 4.05 , the mean was 5.89, and the median was 5.44 (Table 3). The CECs for Hengli, Wanqingsha, and Xinkeng, in the western part of the Jiaomen River, were generally higher than in the east, and the alluvial soil, paddy soil, and swamp soil were about 2-4 times higher than the other soil types. The median and mean contents of the organic matter were $1.82 \%$ and $1.94 \%$, respectively, and the closer they were to the Pearl River estuary, the lower the organic matter content was. 




Figure 4. Contour map of $\mathrm{pH}$, cation exchange capacity (CEC), and soil organic matter (SOM).

Table 3. Descriptive statistics of $\mathrm{pH}$, cation exchange capacity (CEC), and soil organic matter (SOM) in different soil types $(n=348)$.

\begin{tabular}{|c|c|c|c|c|c|c|c|c|c|}
\hline & \multicolumn{3}{|c|}{ Coastal sand $(n=4)$} & \multicolumn{3}{|c|}{ Fluvo-aquic soil $(\mathrm{n}=47)$} & \multicolumn{3}{|c|}{ Red soil $(\mathrm{n}=27)$} \\
\hline & $\mathrm{pH}$ & CEC & SOM & $\mathrm{pH}$ & CEC & SOM & $\mathrm{pH}$ & CEC & SOM \\
\hline $\operatorname{MAX}^{1}$ & 8.30 & 5.52 & 4.05 & 8.28 & 19.65 & 12.17 & 8.43 & 13.81 & 6.87 \\
\hline $\mathrm{MIN}^{2}$ & 6.88 & 3.13 & 0.20 & 4.60 & 2.83 & 0.43 & 4.05 & 4.10 & 0.53 \\
\hline $\mathrm{AVG}^{3}$ & 7.59 & 4.51 & 1.82 & 6.76 & 14.29 & 2.46 & 5.89 & 7.06 & 2.62 \\
\hline $\mathrm{MID}^{4}$ & 7.59 & 4.69 & 1.51 & 6.92 & 16.22 & 2.19 & 5.44 & 6.63 & 2.45 \\
\hline $\mathrm{SD}^{5}$ & 0.64 & 0.87 & 1.60 & 1.04 & 4.71 & 1.62 & 1.19 & 2.35 & 1.38 \\
\hline \multirow[t]{3}{*}{$\mathrm{CV}^{6}$} & 0.08 & 0.19 & 0.88 & 0.15 & 0.33 & 0.66 & 0.20 & 0.33 & 0.53 \\
\hline & \multicolumn{3}{|c|}{ Paddy soil $(\mathrm{n}=158)$} & \multicolumn{3}{|c|}{ Alluvial soil $(\mathrm{n}=32)$} & \multicolumn{3}{|c|}{ Swamp soil $(\mathrm{n}=77)$} \\
\hline & $\mathrm{pH}$ & CEC & SOM & $\mathrm{pH}$ & CEC & SOM & $\mathrm{pH}$ & CEC & SOM \\
\hline $\operatorname{MAX}^{1}$ & 8.13 & 27.54 & 3.53 & 8.28 & 20.80 & 7.04 & 8.43 & 19.99 & 5.82 \\
\hline $\mathrm{MIN}^{2}$ & 4.28 & 7.98 & 0.77 & 4.63 & 4.50 & 0.00 & 5.84 & 5.94 & 0.55 \\
\hline $\mathrm{AVG}^{3}$ & 6.17 & 17.52 & 1.71 & 7.16 & 9.41 & 2.46 & 7.50 & 13.54 & 1.64 \\
\hline $\mathrm{MID}^{4}$ & 6.15 & 17.43 & 1.48 & 7.40 & 8.24 & 2.50 & 7.56 & 14.06 & 1.52 \\
\hline $\mathrm{SD}^{5}$ & 0.98 & 2.89 & 0.57 & 1.00 & 4.10 & 1.31 & 0.37 & 3.31 & 0.79 \\
\hline $\mathrm{CV}^{6}$ & 0.16 & 0.17 & 0.33 & 0.14 & 0.44 & 0.53 & 0.05 & 0.24 & 0.49 \\
\hline
\end{tabular}

${ }^{1}$ Maximum value, ${ }^{2}$ Minimum value, ${ }^{3}$ Average value, ${ }^{4}$ Mid-value, ${ }^{5}$ Standard deviation, ${ }^{6}$ Coefficient of variation.

The $\mathrm{Cd}$ in the Nansha topsoil was $0.01-2.68 \mathrm{mg} / \mathrm{kg}$, and the average and median values were $0.54 \mathrm{mg} / \mathrm{kg}$ and $0.57 \mathrm{mg} / \mathrm{kg}$, respectively, which exceeded the risk screening value of the "Soil Environmental Quality Risk Control Standard for Soil Contamination of Agricultural Land (GB15618-2018)" of $0.3 \mathrm{mg} / \mathrm{kg}$. The soil Cd varied within and between towns, and the soil Cd in Hengli and Xinken farmland soils exceeded $0.6 \mathrm{mg} / \mathrm{kg}$. The contour map for topsoil Cd concentration (Figure 5) shows that the soil Cd distribution in the Nansha district was regular, and that (1) the soil $\mathrm{Cd}$ concentrations in Hengli town, Wanqingsha town, and Xinken town on the southwest bank of the Jiaomen waterway were generally higher than in Nansha on the northeastern bank of the Jiaomen waterway. These differences are related to the landforms and stratum lithologies. The southwest bank of the Jiaomen waterway is a delta alluvial plain, with flat and open terrain and a relative height difference of less than $2 \mathrm{~m}$. The soils belong to the sea-land sea alluvial lantern group $\left(Q_{4 d l}^{3 m c}\right)$. The northeastern bank of the Jiaomen waterway is dominated by a hilly landform and the quaternary strata are alluvial residual soils $\left(Q^{e l}\right)$; (2) there were many $\mathrm{Cd}$ extremities in the soils along both sides of the waterway; (3) the adsorption-desorption of $\mathrm{Cd}$ by soil is affected by soil type, soil solution, and soil chemical, and mineralogical characteristics, including $\mathrm{pH}, \mathrm{SOM}, \mathrm{CEC}$, iron and manganese oxide levels, etc. [37]. However, the $\mathrm{Cd}$ in the soils from the northeastern coast of the Jiamen waterway was generally low, whereas the SOM level was generally high. The $\mathrm{Cd}$ content had a very weak correlation 
with $\mathrm{pH}$, SOM, and CEC, and the correlation coefficients were $0.25,0.159$, and 0.171 , respectively; and (4) the $\mathrm{Cd}$ content varied with soil type. The $\mathrm{Cd}$ content order was coastal sand > swamp soil > paddy soil $>$ fluvo-aquic soil $>$ alluvial soil $>$ red soil (Figure 6 ).



Figure 5. Soil Cd contour distribution.

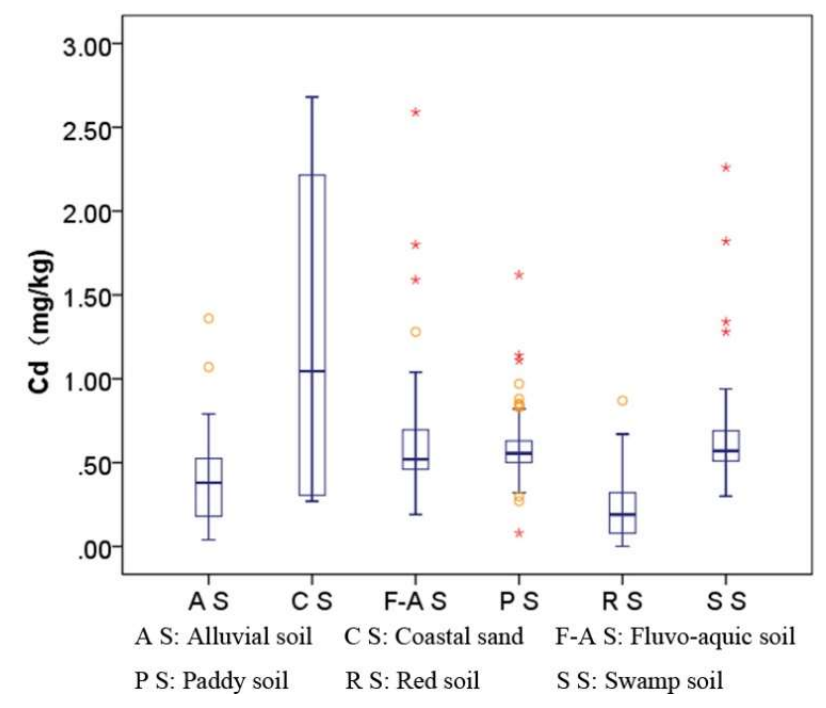

Figure 6. Box charts for Cd content of the different soil types.

\subsection{Factors that Influence Soil Cd Enrichment}

\subsubsection{Topography and the Quaternary Geological Conditions}

The results showed that the distribution of $\mathrm{Cd}$ in topsoil had good corresponding relationships with the topography and quaternary geological conditions. The soil $\mathrm{Cd}$ in the sea-land plains and tidal flats landforms, and the quaternary strata for the lantern in the land-sea alluvial sand group $\left(Q_{4 d l}^{3 m c}\right)$ areas, was significantly higher than for the low hills landform and the alluvial and eluvial soil $\left(Q^{e l}\right)$ regions. The $\mathrm{Cd}$ content also corresponded well to the changes in grain size of the core sediments. The Cd concentration was low in coarse sediment dominated by sandy soil, but high in fine sediment dominated by cohesive soil. The SOM and CEC were both relatively high in the fine-grained sediments dominated by silty clay, which indicates that marine sediments contributed to Cd enrichment [38]. 


\subsubsection{Stream Transport}

Rivers play an important role in receiving and transporting pollutants because they are bodies of water that accept pollutants from both point sources (industry and mining) and non-point sources (urban life, agriculture, and atmospheric precipitation). They are also the sources of large rivers and oceans [39]. Since the 1980s, the rapid economic development of the Pearl River Delta has meant that a large number of heavy metal pollutants have been discharged into the local rivers, and most of them have come from the point sources of Shaoguan, Foshan, Guangzhou, and other big cities with advanced metallurgical and chemical industries. Since 2000, several heavy metal pollution emergencies in tributaries of the Pearl River have been reported $[40,41]$. The maximum values for $\mathrm{Cd}$ were mostly distributed on both sides of the study area watercourse, and the drill core differences for total $\mathrm{Cd}$ were consistent in terms of the geographical location of the drilling in the horizontal plane. The $\mathrm{Cd}$ levels were high in NSGC05 and NSGC11, but were low in NSGC27 and NSGC39, which reflected the sediment quality restrictions on elemental distribution during stream transportation. In general, the NSGC05 and NSGC11 cores contained more sediment transported from the Xijiang and Beijiang rivers, whereas the NSGC27 and NSGC39 contained more sediment from the Dongjiang River. The areas with high Cd contents were mainly distributed in the Xijiang-Beijiang delta sedimentary area, whereas the Dongjiang and the Tanjiang delta sedimentary area had lower Cd contents [42,43]. Therefore, in addition to human activities, stream transport and delta deposition are also factors that have led to the high degree of soil Cd pollution in this study area.

\subsubsection{Physical and Chemical Properties of Soils}

In the topsoil samples, the content of cadmium was weakly correlated with $\mathrm{pH}, \mathrm{SOM}$, and CEC, and the correlation coefficients were $0.25,0.159$, and 0.171 , respectively (Table 4 ), due to different topographies and soil genetic type. However, the trend of $\mathrm{Cd}$ content in soil profile was significantly positively correlated with the trend of SOM and CEC, $P<0.001$, which indicated that SOM and CEC were also important factors affecting the $\mathrm{Cd}$ distribution in the soil. In general, the main influencing factors on the formation of the existing soil Cd distribution pattern in the study area were topography, geological conditions, and stream transport, but soil type and soil physicochemical properties also affected Cd distribution.

Table 4. Correlation and significance of cadmium concentration with cation exchange capacity (CEC), $\mathrm{pH}$, and soil organic matter (SOM) in topsoil and four different cores.

\begin{tabular}{ccccccc}
\hline & & Topsoil & NSGC27 & NSGC05 & NSGC11 & NSGC39 \\
\hline \multirow{2}{*}{ Correlation } & CEC & 0.159 & 0.912 & 0.760 & 0.805 & 0.820 \\
coefficient & pH & 0.250 & -0.124 & -0.177 & -0.155 & -0.333 \\
& SOM & 0.171 & 0.503 & 0.741 & 0.499 & 0.552 \\
\hline \multirow{2}{*}{ Sig (single } & CEC & 0.001 & 0.000 & 0.000 & 0.000 & 0.000 \\
side) & pH & 0.000 & 0.200 & 0.159 & 0.152 & 0.016 \\
& SOM & 0.000 & 0.000 & 0.000 & 0.000 & 0.000 \\
\hline
\end{tabular}

\subsubsection{Human Engineering Activities}

The background Cd concentration of the soil in Guangdong Province is $0.056 \mathrm{mg} / \mathrm{kg}$. The "Risk Screening Values for soil heavy metal: The Pearl River Delta Area (DB44/T1415-2014)" showed that the background concentration for the soil environment in the Pearl River Delta had doubled to $0.11 \mathrm{mg} / \mathrm{kg}$ compared to Guangzhou, whereas the average value for soil $\mathrm{Cd}$ at $1.5 \mathrm{~m}$ to $2.0 \mathrm{~m}$ depths in Nansha was $0.42 \mathrm{mg} / \mathrm{kg}$. This meant that it was three times higher than the background concentration of the soil in the Pearl River Delta, a difference most likely due to differing natural geological factors. The average $\mathrm{Cd}$ concentration in the topsoil $(0.54 \mathrm{mg} / \mathrm{kg})$ was higher than that at $1.5 \mathrm{~m}$ to $2.0 \mathrm{~m}$ depths. The overall spatial variability of the study area was moderate. The CV for paddy soil is $28 \%$, whereas 
our soils were above $65 \%$ because they were more severely affected by human engineering activities. In addition, the variation coefficient for $\mathrm{Cd}$ content in the topsoil $(0-20 \mathrm{~cm})$ was larger than for the deep soil $(20-200 \mathrm{~cm})$. The $\mathrm{Cd}$ concentration for the different deep soils tended to be consistent at the same depth. The above results indicate that human inputs could have polluted the surface soil with Cd to some extent, and that the influence of human activities is random under natural geological conditions.

\subsection{Evaluation of Soil Cd Pollution}

The geo-accumulation index (Igeo) was used to assess pollution in the study area, and the $\mathrm{Cd}$ concentration of the Guangdong Province soil was selected as the geochemical background concentration for $\mathrm{Cd}$ [39] when attempting to describe the high concentrations of heavy metals in sediments. The median Igeo values of each element were in the order $\mathrm{Cd}>\mathrm{Cu}>\mathrm{Zn}>\mathrm{As}>\mathrm{Cr}>$ $\mathrm{Hg}>\mathrm{Pb}$ from large to small (Figure 7), where the mean and median Igeo values for $\mathrm{Pb}, \mathrm{Hg}$, and $\mathrm{Cr}$ were all lower than 1 . The $\mathrm{Pb}, \mathrm{Hg}$, and $\mathrm{Cr}$ levels indicated that the Nansha sediments were generally uncontaminated to moderately contaminated with these metals. However, discrete points appeared locally under the influence of point sources; for example, $\mathrm{Pb}$ levels achieved a heavily contaminated classification, $\mathrm{Hg}$ levels achieved a moderately to heavily contaminated classification, and the largest Igeo $\mathrm{Cr}$ value was 7.19, which was recorded in an extremely contaminated area of the abandoned Meishan industrial park, Huangge town, Nansha District. The pollution classification for As was mainly uncontaminated to moderately contaminated; the maximum Igeo was less than 2, and most local samples were uncontaminated. The pollution classification for $\mathrm{Zn}$ was mainly uncontaminated to moderately contaminated; the maximum Igeo was 3.56 , but some local areas were heavily contaminated. The Igeo for $\mathrm{Cu}$ ranged from -1.61 to 2.41 , which meant that the study area was mainly moderately contaminated, but some local areas were moderately to heavily contaminated. Cadmium had the highest Igeo of 4.99 , the highest Igeo mean of 2.54, and the highest median of 2.68 among all tested metals. This means that $\mathrm{Cd}$ was the most serious polluter of the heavy metals in the study area. Furthermore, human activities had a considerable impact on the ground accumulation index. More than $65 \%$ of the Igeo was within the range of 2 to 3 (Figure 8), which indicated that the study area was mainly moderately to heavily contaminated. However, more than $17 \%$ was heavily contaminated, and some local areas were heavily to extremely contaminated. The variation coefficient for the $\mathrm{Cd}$ Igeo was the smallest among all tested metals $(\mathrm{CV}=37.5 \%)$, which indicates that the $\mathrm{Cd}$ pollution in Nansha District was the most serious among all heavy metal elements, and the most common. In the Nansha District, the results showed that $52 \%$ of the area was considered to be at very high risk from Cd pollution. Furthermore, $36 \%$ for the study area was classified as dangerous, and these areas were mainly distributed in Hengli, Wanqingsha, Xinken, and other towns.



Figure 7. Igeo box plots for each element $(\mathrm{N}=348)$. 




Figure 8. Soil Cd evaluation using the Geological Accumulation Index (left) and the Potential Ecological Risk Index (right) in Nansha District.

In general, human engineering activities have a great impact on Igeo and often result in moderate to heavy contamination. However, Cd pollution distribution is universal, and the potential ecological risk caused by $\mathrm{Cd}$ poses a considerable threat. The natural geological features of the Pearl River Delta and human activity have resulted in moderately to heavily Cd contaminated soil in Nansha. Therefore, it is necessary to determine the influencing factors and the extent of their effects on soil Cd pollution, and to strengthen production management and process controls to prevent continual increases in soil heavy metal contents. Planting structures in farmland also need to be adjusted in order to avoid heavy metal effects on human health via the food chain.

\subsection{Chemical Fractionation of Soil Cd}

\subsubsection{Cd Fractionation and Lability}

It is generally agreed that the harmful effects of heavy metals on human beings and the environment depend not only on their total contents, but also on their chemical composition. After Cd enters the soil, most reacts with inorganic and organic components through adsorption, complexation, or precipitation to form carbonate-bound, humic-acid-bound, Fe-Mn-oxide-bound, organic matter-bound, and other forms. Only a few exist in water-soluble and exchangeable forms, which can effectively affect soil microbial metabolic activity. The water-soluble, exchangeable, and carbonate forms of $\mathrm{Cd}$ in the environment are sensitive to changes in the environment, which may affect activity and migration [44]. The $\mathrm{Cd}$ that is bonded to Fe-Mn oxides, organic matter, and residual forms is relatively stable in the environment and has weak activity. Therefore, the instability of $\mathrm{Cd}$ needs to be characterized using the sum of the water-soluble, ion-exchange, and carbonate forms, which is called labile Cd. The contribution rate of each component to the total concentration (Figure 9) indicated that in all the core sections, the proportion of the water-soluble form was relatively low, whereas the exchange form and carbonate form proportions were relatively high. The labile $\mathrm{Cd}$ proportion ranged from $37.92 \%$ to $47.49 \%$, and averaged $44.19 \%$ of the total Cd. 

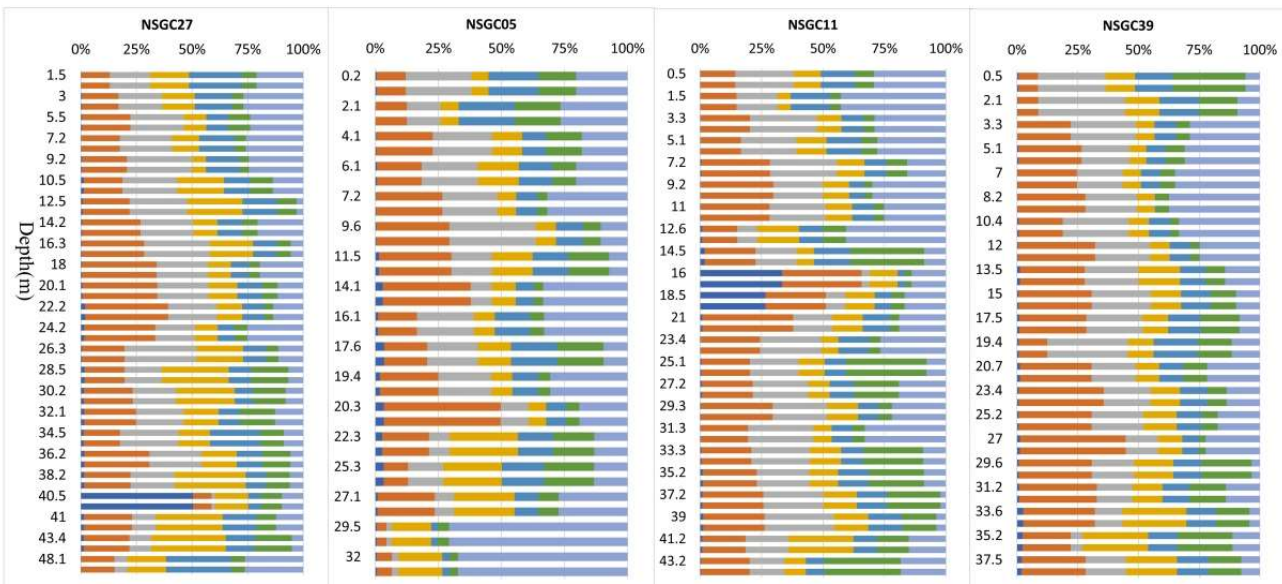

Figure 9. Percentage of $\mathrm{Cd}$ fractionation in each core.

\subsubsection{Bioavailability of $\mathrm{Cd}$ across the Area}

The order of bioavailability of different heavy metal forms in soil by sequential extraction procedures was: water-soluble $>$ exchangeable form $>$ carbonate-bound $>$ humic-acid-bound $>$ Fe-Mn-oxide-bound $>$ organic-matter-bound $>$ residual form $[45,46]$. The fractions were classified into three bioavailable categories: easily bioavailable, moderately bioavailable, and inertly bioavailable [47]. Easily bioavailable $\mathrm{Cd}$ is the sum of water-soluble and exchangeable form, which has great mobility and is most easily absorbed by organisms. The moderately bioavailable $\mathrm{Cd}$ is the sum of the carbonate, humic acid, Fe-Mn oxide, and organic matter forms, which can be converted into bioavailable $\mathrm{Cd}$ under strong acid or other appropriate conditions. The inertly bioavailable or residual form has little effect on the migration and bioavailability of cadmium in soil. The bioavailability of $\mathrm{Cd}$ in the study area indicated that the bioavailable Cd in cores ranged from 0.004 to $0.37 \mathrm{mg} / \mathrm{kg}$, with an average of $0.064 \mathrm{mg} / \mathrm{kg}$, and moderately bioavailable ranged from 0.022 to $0.336 \mathrm{mg} / \mathrm{kg}$, with an average of 0.126 $\mathrm{mg} / \mathrm{kg}$ (Table 5). The bioavailable and moderately bioavailable Cd values were generally higher at sampling depths of less than 20 meters (Figure 10), and the average of the bioavailable and moderately bioavailable Cd was 0.077 and $0.156 \mathrm{mg} / \mathrm{kg}$, respectively, while the values taken at sampling depths of more than 30 meters were generally lower, and the average of the bioavailable and moderately bioavailable Cd was 0.024 and $0.064 \mathrm{mg} / \mathrm{kg}$, respectively.

Table 5. Descriptive statistics of bioavailable and moderately bioavailable $\mathrm{Cd}$ in each core.

\begin{tabular}{ccccccccc}
\hline \multirow{2}{*}{$\begin{array}{c}\text { Boring } \\
\text { Number }\end{array}$} & \multicolumn{4}{c}{ Bioavailable Cd } & \multicolumn{4}{c}{ Moderately Bioavailable Cd } \\
\cline { 2 - 9 } & NSGC27 & NSGC05 & NSGC11 & NSGC39 & NSGC27 & NSGC05 & NSGC11 & NSGC39 \\
\hline MAX & 0.127 & 0.202 & 0.370 & 0.220 & 0.242 & 0.336 & 0.277 & 0.308 \\
MIN & 0.012 & 0.004 & 0.013 & 0.010 & 0.039 & 0.022 & 0.038 & 0.029 \\
AVG & 0.051 & 0.062 & 0.077 & 0.060 & 0.117 & 0.128 & 0.137 & 0.123 \\
0-20 m AVG & 0.056 & 0.084 & 0.104 & 0.063 & 0.146 & 0.165 & 0.157 & 0.154 \\
$>30$ m AVG & 0.029 & 0.010 & 0.035 & 0.022 & 0.069 & 0.045 & 0.100 & 0.043 \\
\hline
\end{tabular}



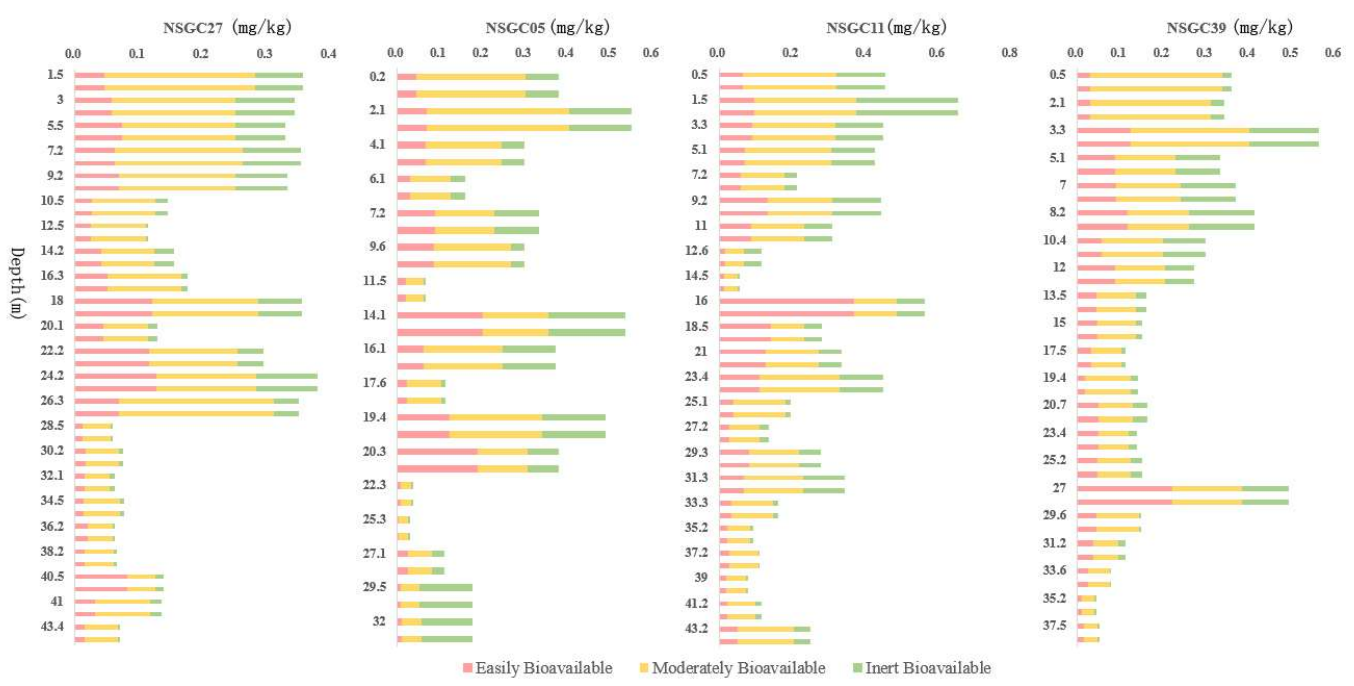

Figure 10. Bioavailability of $\mathrm{Cd}$ in each core.

\subsubsection{Factors Affecting Bioavailable Cd}

Bioavailable $\mathrm{Cd}$ is considered to be a multi-equilibrium fraction between the solution and soil constituents [48], and positively correlated to the immobilized Cd in soil constituents. The majority of the soil $\mathrm{Cd}$ was bonded to the solid constituents and determined the total $\mathrm{Cd}$ in the studied soils. Therefore, there was usually a significant correlation between labile and total Cd [17]. The labile Cd largely depends on the total amount and source of $\mathrm{Cd}$ in soils. The difference in the fractionation between the four profiles corresponded to the difference in the total $\mathrm{Cd}$. The fractionation characteristics of Cd in the NSGC05 and NSGC11 profiles were relatively similar, and there was little difference between the proportions of each form in the two profiles. The $\mathrm{Cd}$ fractionation characteristics in the NSGC27 and NSGC39 profiles were also similar, and the contribution rate of each form to the total content was relatively stable. This further reflected the Cd source differences between NSGC05/NSGC11 and NSGC27/NSGC39. Factor analysis of total, bioavailable, and labile Cd (Table 6) showed that the total $\mathrm{Cd}$ in the soil had a strong positive correlation with bioavailable $\mathrm{Cd}$, and an extremely strong positive correlation with labile $\mathrm{Cd}$. The correlation coefficients for total $\mathrm{Cd}$ and labile $\mathrm{Cd}$ were 0.893 , $0.891,0.898$, and 0.977 for each profile, respectively, while the correlation coefficients for total $\mathrm{Cd}$ and bioavailable Cd were $0.780,0.773,0.679$, and 0.787 for each profile, respectively.

Table 6. Correlation coefficients for total, bioavailable, and labile $\mathrm{Cd}$ in each profile.

\begin{tabular}{|c|c|c|c|c|c|c|c|c|c|c|c|c|}
\hline \multirow{2}{*}{ Fractions } & \multicolumn{3}{|c|}{ NSGC27 } & \multicolumn{3}{|c|}{ NSGC05 } & \multicolumn{3}{|c|}{ NSGC11 } & \multicolumn{3}{|c|}{ NSGC39 } \\
\hline & Total & Bioavailable & Labile & Total & Bioavailable & Labile & Total & Bioavailable & Labile & Total & Bioavailable & Labile \\
\hline Total & 1.00 & 0.780 & 0.893 & 1.00 & 0.773 & 0.891 & 1.00 & 0.679 & 0.898 & 1.00 & 0.787 & 0.977 \\
\hline Bioavailable & 0.780 & 1.00 & 0.916 & 0.773 & 1.00 & 0.920 & 0.679 & 1.00 & 0.908 & 0.787 & 1.00 & 0.885 \\
\hline Labile & 0.893 & 0.916 & 1.00 & 0.891 & 0.920 & 1.00 & 0.898 & 0.908 & 1.00 & 0.977 & 0.885 & 1.00 \\
\hline Water-soluble & -0.064 & 0.266 & 0.030 & 0.555 & 0.876 & 0.696 & 0.345 & 0.877 & 0.635 & 0.390 & 0.674 & 0.478 \\
\hline Exchangeable & 0.827 & 0.917 & 0.928 & 0.782 & 0.999 & 0.928 & 0.841 & 0.892 & 0.962 & 0.790 & 1.00 & 0.887 \\
\hline Carbonate & 0.846 & 0.653 & 0.902 & 0.774 & 0.478 & 0.783 & 0.749 & 0.121 & 0.526 & 0.895 & 0.457 & 0.819 \\
\hline Humic acid & 0.756 & 0.397 & 0.534 & 0.843 & 0.640 & 0.671 & 0.831 & 0.747 & 0.869 & 0.843 & 0.592 & 0.809 \\
\hline $\mathrm{Fe}-\mathrm{Mn}$ oxide & 0.773 & 0.314 & 0.430 & 0.778 & 0.331 & 0.541 & 0.795 & 0.170 & 0.484 & 0.674 & 0.243 & 0.582 \\
\hline Organic & 0.796 & 0.527 & 0.620 & 0.622 & 0.174 & 0.364 & -0.004 & -0.202 & -0.164 & 0.388 & -0.084 & 0.233 \\
\hline Residual & 0.932 & 0.655 & 0.746 & 0.800 & 0.539 & 0.558 & 0.893 & 0.339 & 0.633 & 0.868 & 0.777 & 0.869 \\
\hline
\end{tabular}

The variation coefficient can reflect the fluctuation range of statistical data. The variation coefficient results for $\mathrm{Cd}$ fractionation in each core (Table 7) showed that the average level for the water-soluble variation coefficient was high, and its dispersion degree was greater. NSGC27 and NSGC11 were as high as $321.79 \%$ and $264.81 \%$, respectively. However, the remaining morphological variation coefficients were relatively stable. Figure 8 also shows that both NSGC27 and NSGC11 had abnormal water-soluble points. The water-soluble Cd in NSGC27 at the depth of $40.7 \mathrm{~m}$ was $0.07 \mathrm{mg} / \mathrm{kg}$, which accounted for $50.45 \%$ of the total $\mathrm{Cd}$. The corresponding $\mathrm{pH}$ was 3.51 . The water-soluble Cd in NSGC11 
at depths of $16.2 \mathrm{~m}$ and $18.8 \mathrm{~m}$ were 0.188 and $0.074 \mathrm{mg} / \mathrm{kg}$, respectively, which accounted for $33.38 \%$ and $26.54 \%$ of the total $\mathrm{Cd}$, and the corresponding $\mathrm{pH}$ values were 4.03 and 4.21 , respectively. The remaining samples were basically neutral to weakly alkaline, and the water-soluble contents were all less than $0.006 \mathrm{mg} / \mathrm{kg}$. It is generally accepted that $\mathrm{pH}$ is one of the most important factors affecting $\mathrm{Cd}$ migration and transformation, but the negative correlation between the $\mathrm{pH}$ and the total $\mathrm{Cd}$ in the drilled samples was not significant because the $\mathrm{pH}$ values of the tested soil samples were generally neutral to weakly alkaline. In spite of this, the absolute values of the correlation coefficients between $\mathrm{pH}$ and the water-soluble $\mathrm{Cd}$ were greater than $0.6(\mathrm{P}<0.01)$, and the squared correlation coefficients $\left(\mathrm{R}^{2}\right)$ were $0.9833,0.7029,0.8422$, and 0.8225 for the four profiles, respectively, which showed that there was a significant negative correlation between $\mathrm{pH}$ and water-soluble $\mathrm{Cd}$. As $\mathrm{pH}$ increased, the water-soluble $\mathrm{Cd}$ decreased in an "inverted J" type manner, and when the $\mathrm{pH}$ exceeded 7, the water-soluble $\mathrm{Cd}$ approached the detection limit (Figure 11). The above results showed that the influence of $\mathrm{pH}$ on the migration and transformation of $\mathrm{Cd}$ was mainly to change the bioavailability of $\mathrm{Cd}$, rather than the total Cd levels, which affected the ecological effectiveness of $\mathrm{Cd}$.

Table 7. \% Total and variation coefficients for Cd fractionation in each core.

\begin{tabular}{ccccccccc}
\hline \multirow{2}{*}{ Fractionation } & \multicolumn{4}{c}{$\%$ Total (\%) } & \multicolumn{4}{c}{ Variation Coefficients (\%) } \\
\cline { 2 - 9 } & NSGC27 & NSGC05 & NSGC11 & NSGC39 & NSGC27 & NSGC05 & NSGC11 & NSGC39 \\
\hline Water-soluble & 3.07 & 1.44 & 3.15 & 0.89 & 321.79 & 83.19 & 264.81 & 70.9 \\
Exchangeable & 22.13 & 20.31 & 22.69 & 25.65 & 31.5 & 51.47 & 25.69 & 32.81 \\
Carbonate & 20.43 & 16.17 & 19.86 & 20.95 & 35.29 & 53.01 & 32.56 & 33.04 \\
Humic acid & 18.06 & 13.37 & 11.56 & 12.93 & 42.07 & 47.76 & 35.56 & 44.02 \\
Fe-Mn oxide & 13.01 & 11.86 & 10.22 & 10.82 & 42.07 & 45.07 & 29.66 & 33.37 \\
Organic & 8.83 & 10.2 & 12.3 & 11.39 & 43.99 & 57.61 & 79.45 & 59.94 \\
Residual & 14.46 & 26.66 & 20.22 & 17.36 & 53.79 & 65.73 & 53.56 & 59.92 \\
\hline
\end{tabular}

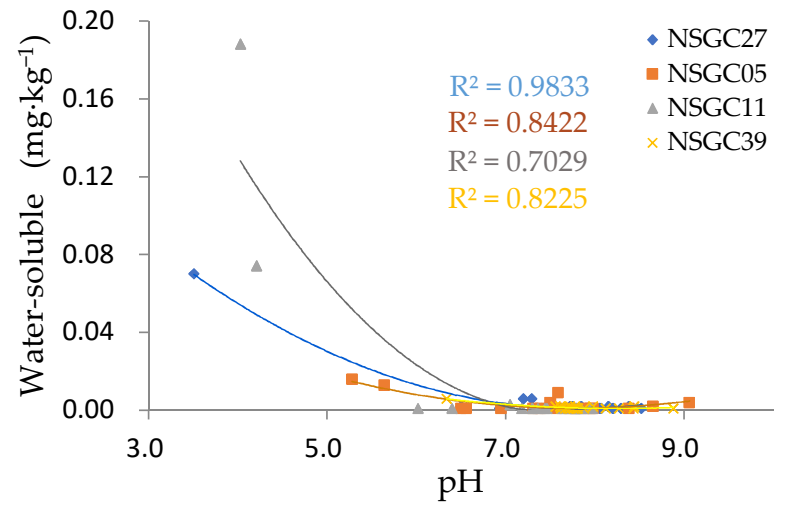

Figure 11. Correlation between $\mathrm{Cd}$ water solubility and the $\mathrm{pH}$ value for each core.

\section{Conclusions}

The soil Cd concentration in Nansha District was significantly higher than the background concentration for Guangdong Province. It exceeded the risk screening value in the Soil Environmental Quality Risk Control Standard for Soil Contamination of Agricultural Land (GB15618-2018) of $0.3 \mathrm{mg} / \mathrm{kg}$. The topsoil $\mathrm{Cd}$ had good corresponding relationships with topography, quaternary geological conditions, and soil type. Namely, the $C d$ in the land-sea alluvial sand group $\left(Q_{4 d l}^{3 m c}\right)$ areas was significantly higher than in the alluvial and eluvial soil $\left(Q^{e l}\right)$ regions, which corresponded to the grain size of the core sediments, and was ranked as coastal sand $>$ swamp soil $>$ paddy soil $>$ fluvo-aquic soil $>$ alluvial soil $>$ red soil. Heavy metal pollution events frequently occur in tributaries of the Pearl River, and the rivers receive and transport pollutants. Therefore, river transport affects the distribution of $\mathrm{Cd}$. Human engineering activities have had a considerable impact on the Igeo value and have resulted in moderate to heavy contamination, which has led to a potential ecological risk. The CV for Cd in topsoil (0-20 cm) was greater than for deep soil $(20-200 \mathrm{~cm})$, but the Cd levels tended to be 
the same as depth increased. There was a strong positive correlation between total $\mathrm{Cd}$ and bioavailable $\mathrm{Cd}$ in soil, and there was an extremely strong positive correlation with labile $\mathrm{Cd}$, which accounted for about half of the total $\mathrm{Cd}$. The influence of $\mathrm{pH}$ on the migration and transformation of $\mathrm{Cd}$ was mainly to change the bioavailable $\mathrm{Cd}$ rather than the total $\mathrm{Cd}$ levels, which affected the bioavailability of $\mathrm{Cd}$. The bioavailable and moderately bioavailable $\mathrm{Cd}$ contents at sampling depths of less than 20 meters were generally higher than at the sampling depths of more than 30 meters. Furthermore, the change trend for $\mathrm{Cd}$ in soil profile was significantly positively correlated with soil organic matter (SOM) and cation exchange capacity (CEC), which indicates that the physical and chemical properties of the soil also affected the distribution of $\mathrm{Cd}$. Effective treatment should be used to immobilize $\mathrm{Cd}$ before reclaiming these soils and prevent heavy metal increases in farmland, and the planting structure should be adjusted to avoid the impact of heavy metals on human health through ingestion via the food chain.

Author Contributions: Conceptualization, C.H. and Z.C.; Data curation, F.W. and K.B.; Formal analysis, F.W. and K.B.; Funding acquisition, C.H.; Investigation, F.W., C.H. and K.B.; Methodology, Z.C.; Project administration, C.H.; Resources, C.H.; Software, F.W. and K.B.; Supervision, Z.C.; Validation, K.B.; Visualization, F.W.; Writing—original draft, F.W.; Writing—review \& editing, F.W., Z.C. and K.B.

Funding: This research was funded by Wuhan Geological Survey Center, China Geological Survey, grant number DD20190291. The APC was funded by Guangzhou Multi-Element Urban Geological Survey Project.

Acknowledgments: The authors are grateful to the support provided by School of Environmental Studies, China University of Geosciences and the financial support provided by Guangzhou multi-element urban geological survey project. The anonymous editor and reviewers have also contributed considerably to the publication of this paper. I would like to thank the anonymous editor and reviewers who helped to improve the paper.

Conflicts of Interest: The authors declare no conflict of interest.

\section{References}

1. Li, F.; Zhang, J.D.; Huang, J.H.; Huang, D.; Yang, J.; Song, Y.; Zeng, G. Heavy metals in road dust from Xiandao District, Changsha City, China: Characteristics, health risk assessment, and integrated source identification. Environ. Sci. Pollut. Res. 2016, 23, 13100-13113. [CrossRef] [PubMed]

2. Wang, M.E.; Liu, R.; Chen, W.P.; Peng, C.; Markert, B. Effects of urbanization on heavy metal accumulation in surface soils, Beijing. J. Environ. Sci. 2018, 64, 328-334. [CrossRef] [PubMed]

3. Li, F.; Huang, J.H.; Zeng, G.M.; Liu, W.; Huang, X.; Huang, B.; Gu, Y.; Shi, L.; He, X.; He, Y. Toxic metals in topsoil under different land uses from Xiandao District, middle China: Distribution, relationship with soil characteristics, and health risk assessment. Environ. Sci. Pollut. Res. 2015, 22, 12261-12275. [CrossRef] [PubMed]

4. Peng, C.; Wang, M.; Chen, W.P. Modelling cadmium contamination in paddy soils under long-term remediation measures: Model development and stochastic simulations. Environ. Pollut. 2016, 216, $146-155$. [CrossRef] [PubMed]

5. Xie, Y.F.; Chen, T.B.; Lei, M.; Yang, J.; Guo, Q.J.; Song, B.; Zhou, X.Y. Spatial distribution of soil heavy metal pollution estimated by different interpolation methods: Accuracy and uncertainty analysis. Chemosphere 2011, 82, 468-476. [CrossRef] [PubMed]

6. Li, Q.Q.; Wang, C.Q.; Dai, T.F.; Shi, W.; Zhang, X.; Xiao, Y.; Song, W.; Li, B.; Wang, Y. Prediction of soil cadmium distribution across a typical area of Chengdu Plain, China. Sci. Rep. 2017, 7, 7115. [CrossRef] [PubMed]

7. Satarug, S.; Garrett, S.H.; Sens, M.A.; Sens, D.A. Cadmium, Environmental Exposure, and Health Outcomes. Environ. Health Perspect. 2010, 118, 182-190. [CrossRef]

8. Dong, R.Z.; Jia, Z.M.; Li, S.Y. Risk assessment and sources identification of soil heavy metals in a typical county of Chongqing Municipality, Southwest China. Process Saf. Environ. Prot. 2018, 113, 275-281. [CrossRef]

9. Huang, Y.; Li, T.Q.; Wu, C.X.; He, Z.; Japenga, J.; Deng, M.; Yang, X. An integrated approach to assess heavy metal source apportionment in pen-urban agricultural soils. J. Hazard. Mater. 2015, 299, 540-549. [CrossRef]

10. Luo, Q.; Wang, K.; Xu, J.-B.; Chen, G. Cadmium Pollution Situation, Harm, Source and Production Measures in Paddy Field of China. J. Anhui Agric. Sci. 2014, 42, 10540-10542. 
11. Zhang, H.; Luo, Y.; Zhang, H.; Song, J.; Xia, J.; Zhao, Q. Study on Soil Environmental Quality Guidelines and Standards V. Modeling of Cadmium Uptake in Soil-Crop Systems for Human Food Safety in China. Acta Pedol. Sin. 2010, 47, 628-638.

12. Li, B.; Xiao, R.; Wang, C.Q.; Cao, L.; Zhang, Y.; Zheng, S.; Yang, L.; Guo, Y. Spatial distribution of soil cadmium and its influencing factors in peri-urban farmland: A case study in the Jingyang District, Sichuan, China. Environ. Monit. Assess. 2017, 189, 21. [CrossRef] [PubMed]

13. Zu, Y.Q.; Bock, L.; Schvartz, C.; Colinet, G.; Li, Y. Mobility and distribution of lead, cadmium, copper and zinc in soil profiles in the peri-urban market garden of Kunming, Yunnan Province, China. Arch. Agron. Soil Sci. 2014, 60, 133-149. [CrossRef]

14. Wang, D.F.; Wei, Z.Y.; Tang, S.M.; Qi, Z. Distribution of selenium and cadmium in soil-rice system of selenium-rich area in Hainan, China. Pak. J. Pharm. Sci. 2014, 27, 1633-1639. [PubMed]

15. Agca, N.; Ozdel, E. Assessment of spatial distribution and possible sources of heavy metals in the soils of Sariseki-Dortyol District in Hatay Province (Turkey). Environ. Earth Sci. 2014, 71, 1033-1047. [CrossRef]

16. Romic, M.; Romic, D. Heavy metals distribution in agricultural topsoils in urban area. Environ. Geol. 2003, 43, 795-805. [CrossRef]

17. He, S.R.; Lu, Q.; Li, W.Y.; Ren, Z.; Zhou, Z.; Feng, X.; Zhang, Y.; Li, Y. Factors controlling cadmium and lead activities in different parent material-derived soils from the Pearl River Basin. Chemosphere 2017, 182, 509-516. [CrossRef]

18. Liu, G.N.; Wang, J.; Xue, W.; Zhao, J.; Wang, J.; Liu, X. Effect of the size of variable charge soil particles on cadmium accumulation and adsorption. J. Soils Sediments 2017, 17, 2810-2821. [CrossRef]

19. Kim, S.U.; Owens, V.N.; Kim, Y.G.; Lee, S.M.; Park, H.C.; Kim, K.K.; Son, H.J.; Hong, C.O. Effect of Phosphate Addition on Cadmium Precipitation and Adsorption in Contaminated Arable Soil with a Low Concentration of Cadmium. Bull. Environ. Contam. Toxicol. 2015, 95, 675-679. [CrossRef]

20. Zhao, X.L.; Jiang, T.; Du, B. Effect of organic matter and calcium carbonate on behaviors of cadmium adsorption-desorption on/from purple paddy soils. Chemosphere 2014, 99, 41-48. [CrossRef]

21. Jiang, H.; Li, T.Q.; Han, X.; Yang, X.; He, Z. Effects of $\mathrm{pH}$ and low molecular weight organic acids on competitive adsorption and desorption of cadmium and lead in paddy soils. Environ. Monit. Assess. 2012, 184, 6325-6335. [CrossRef] [PubMed]

22. Medina, I. Determination of diffusion coefficients for supercritical fluids. J. Chromatogr. A 2012, 1250, $124-140$. [CrossRef] [PubMed]

23. Gallon, C.; Ranville, M.A.; Conaway, C.H.; Landing, W.M.; Buck, C.S.; Morton, P.L.; Flegal, A.R. Asian Industrial Lead Inputs to the North Pacific Evidenced by Lead Concentrations and Isotopic Compositions in Surface Waters and Aerosols. Environ. Sci. Technol. 2011, 45, 9874-9882. [CrossRef] [PubMed]

24. Okin, G.S.; Parsons, A.J.; Wainwright, J.; Herrick, J.E.; Bestelmeyer, B.T.; Peters, D.C.; Fredrickson, E.L. Do Changes in Connectivity Explain Desertification? Bioscience 2009, 59, 237-244. [CrossRef]

25. Filippelli, G.M.; Morrison, D.; Cicchella, D. Urban Geochemistry and Human Health. Elements 2012, 8, 439-444. [CrossRef]

26. Csavina, J.; Landazuri, A.; Wonaschutz, A.; Rine, K.; Rheinheimer, P.; Barbaris, B.; Conant, W.; Sáez, A.E.; Betterton, E.A. Metal and Metalloid Contaminants in Atmospheric Aerosols from Mining Operations. Water Air Soil Pollut. 2011, 221, 145-157. [CrossRef] [PubMed]

27. Hua, Z. Recent progress in the study of heavy metal bioavailability in soil. Geophys. Geochem. Explor. 2014, $38,1097-1106$.

28. Müller, G. Index of geoaccumulation in sediments of the Rhine rive. Geojournal 1969, 2, 108-118.

29. Hakanson, L. An ecological risk index for aquatic pollution control.a sedimentological approach. Water Res. 1980, 14, 975-1001. [CrossRef]

30. Saeedi, M.; Jamshidi-Zanjani, A. Development of a new aggregative index to assess potential effect of metals pollution in aquatic sediments. Ecol. Indic. 2015, 58, 235-243. [CrossRef]

31. Liu, Y.Z.; Xiao, T.F.; Baveye, P.C.; Zhu, J.; Ning, Z.; Li, H. Potential health risk in areas with high naturally-occurring cadmium background in southwestern China. Ecotoxicol. Environ. Saf. 2015, 112, 122-131. [CrossRef]

32. Cheng, S.W.; Liu, G.J.; Zhou, C.C.; Sun, R. Chemical speciation and risk assessment of cadmium in soils around a typical coal mining area of China. Ecotoxicol. Environ. Saf. 2018, 160, 67-74. [CrossRef] 
33. Yongming, H.; Peixuan, D.; Junji, C.; Posmentier, E.S. Multivariate analysis of heavy metal contamination in urban dusts of Xi'an, Central China. Sci. Total Environ. 2006, 355, 176-186. [CrossRef]

34. Tahri, M.; Benyaich, F.; Bounakhla, M.; Bilal, E.; Gruffat, J.J.; Moutte, J.; Garcia, D. Multivariate analysis of heavy metal contents in soils, sediments and water in the region of Meknes (central Morocco). Environ. Monit. Assess. 2005, 102, 405-417. [CrossRef]

35. Zahra, A.; Hashmi, M.Z.; Malik, R.N.; Ahmed, Z. Enrichment and geo-accumulation of heavy metals and risk assessment of sediments of the Kurang Nallah-Feeding tributary of the Rawal Lake Reservoir, Pakistan. Sci. Total Environ. 2014, 470, 925-933. [CrossRef]

36. Varol, M. Assessment of heavy metal contamination in sediments of the Tigris River (Turkey) using pollution indices and multivariate statistical techniques. J. Hazard. Mater. 2011, 195, 355-364. [CrossRef]

37. Loganathan, P.; Vigneswaran, S.; Kandasamy, J.; Naidu, R. Cadmium Sorption and Desorption in Soils: A Review. Crit. Rev. Environ. Sci. Technol. 2012, 42, 489-533. [CrossRef]

38. Lai, Q.; Yu, H.; Li, G.; Xia, B. Chemical Characteristics of Soil Cd-High Areas in Zhujiang Delta. Geophys. Geochem. Explor. 2005, 29, 334-335, 341. (In Chinese)

39. Liao, J.; Chen, J.; Ru, X.; Chen, J.; Wu, H.; Wei, C. Heavy metals in river surface sediments affected with multiple pollution sources, South China: Distribution, enrichment and source apportionment. J. Geochem. Explor. 2017, 176, 9-19. [CrossRef]

40. Dou, M.; Zuo, Q.T.; Zhang, J.P.; Li, C.; Li, G. Influence of changes in hydrodynamic conditions on cadmium transport in tidal river network of the Pearl River Delta, China. Environ. Monit. Assess. 2013, 185, 7501-7516. [CrossRef]

41. Song, M.W.; Huang, P.; Li, F.; Zhang, H.; Xie, K.Z.; Wang, X.H.; He, G.X. Water quality of a tributary of the Pearl River, the Beijiang, Southern China: Implications from multivariate statistical analyses. Environ. Monit. Assess. 2011, 172, 589-603. [CrossRef]

42. Tang, Z.; Hou, Q.; You, Y.; Yang, Z.; Li, K. Distribution Characteristics and Influencing Factors of Heavy Metals in Pearl River Delta Quaternary Boreholes. Adv. Earth Sci. 2017, 32, 885-898.

43. Luo, X.; Guo, Q.; Xie, Z.; Yang, J.; Chai, Z.; Liu, X.; Wu, S. Study on heavy metal pollution in typical rural soils in Pearl River Delta area. Ecol. Environ. Sci. 2014, 23, 485-489.

44. Li, F.; Zhang, J.; Liu, W.; Liu, J.; Huang, J.; Zeng, G. An exploration of an integrated stochastic-fuzzy pollution assessment for heavy metals in urban topsoil based on metal enrichment and bioaccessibility. Sci. Total Environ. 2018, 644, 649-660. [CrossRef]

45. Xian, X. Effect of Chemical Forms of Cadmium, Zinc, and Lead in Polluted Soils on Their Uptake by Cabbage Plants. Plant Soil 1989, 113, 257-264. [CrossRef]

46. Ma, L.Q.; Rao, G.N. Chemical fractionation of cadmium, copper, nickel, and zinc in contaminated soils. J. Environ. Qual. 1997, 26, 259-264. [CrossRef]

47. Mao, M.; Liu, Z.; Dong, H.; Wang, H.; Shi, S.; Lin, Z.; Peng, X. Distribution and speciation of metals in sediments along Le An River. J. Environ. Sci. 1992, 4, 72-81.

48. Ren, Z.L.; Tella, M.; Bravin, M.N.; Comans, R.N.J.; Dai, J.; Garnier, J.; Sivry, Y.; Doelsch, E.; Straathof, A.; Benedettia, M.F. Effect of dissolved organic matter composition on metal speciation in soil solutions. Chem. Geol. 2015, 398, 61-69. [CrossRef]

(C) 2019 by the authors. Licensee MDPI, Basel, Switzerland. This article is an open access article distributed under the terms and conditions of the Creative Commons Attribution (CC BY) license (http://creativecommons.org/licenses/by/4.0/). 